\title{
12. MIDDLE MIOCENE CARBONATE GRAVITY FLOWS IN THE STRAITS OF FLORIDA AT SITE 626 ${ }^{1}$
}

\author{
Craig S. Fulthorpe ${ }^{2}$ and Allan J. Melillo ${ }^{3}$
}

\begin{abstract}
Cores 101-626C-13H through 101-626C-18H recovered from Hole $626 \mathrm{C}$ in the Straits of Florida contain thick, carbonate sediment gravity-flow deposits that accumulated during a relatively brief period in the middle Miocene. Individual flow deposits are up to $19 \mathrm{~m}$ thick and contain chalk and limestone clasts in a matrix of muddy carbonate sand. These clasts normally are graded in some intervals. Both debris flows and high-density turbidity currents probably were involved in this sediment transportation. One deposit (at least) appears to be a composite flow, comprising a basal debris flow and an overlying turbidity current. The clasts and matrix contain skeletal fragments of both neritic and pelagic origins, and the flows probably resulted from failure of the upper slope of a carbonate platform that was located east of Site 626. Overloading of the slope with bank-derived sediment during middle Miocene sea-level highstands may have led to instability. Correlation with flow deposits of the Great Abaco Member of the Blake Ridge Formation (in the BlakeBahama Basin), slump deposits north of Little Bahama Bank, and a middle Miocene slide scar on the western Florida margin, however, suggests that slope failure was triggered by tectonic activity.
\end{abstract}

\section{INTRODUCTION}

In this paper we discuss the sedimentology of a 50-m interval of middle Miocene, clast-bearing, carbonate sediment that was cored at Site 626 in the Straits of Florida (Fig. 1). We interpret the sediment to have been deposited by gravity flows having the characteristics of debris flows and high-density turbidity currents. We suggest that, in at least one case, both flow mechanisms operated in a single flow. Possible causes of the sediment gravity flows are (1) gravitational instability caused by sediment loading of a carbonate platform slope during a period of rising sea level, (2) triggering of slope failure by a decrease in sea level, or (3) triggering by earthquake activity.

Several other sediment gravity-flow events occurred in the region during the same period (Fig. 1), lower to middle Miocene sediment gravity-flow deposits were cored at Sites 627 and 628 and large middle Miocene slumps were identified from seismic profiles north of Little Bahama Bank near Sites 627 and 628 (Harwood and Towers, this volume). However, these deposits differ in scale and lithology from those at Site 626. The Great Abaco Member of the Blake Ridge Formation in the Blake-Bahama Basin, penetrated at DSDP Sites 391 (Benson, Sheridan, et al., 1978) and 534 (Sheridan, Gradstein, et al., 1983), contains gravity-flow deposits that span most of the Miocene, with sedimentation-rate peaks in the middle Miocene. Off the west coast of Florida, Mullins et al. (1986) documented a middle Miocene slide scar that resulted from the failure of a $120-\mathrm{km}$ length of the western margin of the Florida carbonate platform. The timing of these flow events suggests the possibility of a common cause.

\section{STRATIGRAPHY AND LITHOLOGY}

Drilling at Site 626 penetrated a sequence of upper Oligocene to Pleistocene carbonate sediments, to a total depth of 446.8 meters below sea floor (mbsf). Although four holes (626A

\footnotetext{
${ }^{1}$ Austin, J. A., Jr., Schlager, W., et al., 1987. Proc. ODP, Sci. Results, 101: College Station, TX (Ocean Drilling Program).

2 Department of Geological Sciences, Northwestern University, Evanston, IL 60201 .

${ }^{3}$ Rutgers University, New Brunswick, NJ. Present address: Chevron U.S.A., 935 Gravier Street, New Orleans, LA 70112.
}

through 626D) were drilled at the site, most core recovery was from Holes $626 \mathrm{C}$ and $626 \mathrm{D}$. Hole $626 \mathrm{C}$ was cored continuously to a total depth of $179.3 \mathrm{mbsf}$, while Hole $626 \mathrm{D}$ was drilled to 446.8 mbsf, with continuous coring only between 179.4 and 446.8 mbsf.

The sediment sequence was divided into three lithologic units (Units I, II, and III) by Austin, Schlager, et al. (1986), with the clast-bearing sediment occurring in Unit II. Unit II is contained within the interval sampled using the hydraulic piston coring (HPC) system (Cores 101-626C-13H through 101-626C-19H) (Fig. 2). Above and below this interval recovery was poor, but the nature of the sediment could be inferred using seismic stratigraphy, laboratory velocity measurements, downhole porosity measurements, and examination of the cores.

Below Unit II, Unit III contains middle Miocene to upper Oligocene unlithified, current-winnowed, planktonic foraminifer, skeletal-fragment packstone and grainstone, with occasional fragments of lithified packstone and grainstone. The lithified fragments were interpreted by Austin, Schlager, et al. (1986) as deriving from hard layers separated by unlithified sediment. Above Unit II, the sediment of Unit I consists predominantly of unlithified, current-winnowed, planktonic foraminifer, skeletalfragment packstone and grainstone of Pleistocene to middle Miocene age with no evidence of lithified clasts or layers (Austin, Schlager, et al. 1986).

The clast-bearing sediment of Unit II, between approximately 120 and 170 mbsf, exhibited a combination of high drilling rate, reduced porosity, hummocky basal reflector, and lack of continuous internal reflectors (Figs. 3 and 4). This interval is unique at Site 626 down to the maximum drilled depth of 446.8 mbsf. Austin, Schlager, et al. (1986) concluded that during the middle Miocene, a series of large sediment gravity flows interrupted the normal deposition of current-winnowed sediment. Unit II pinches out to the west, suggesting that the flows originated on the eastern side of the straits (Fig. 3). A pinch-out to the north is associated with an upward slope of the base of Unit II, suggesting that its thickness in this direction is topographically controlled (Fig. 4). An unconformity exists between Units II and III (Austin, Schlager, et al., 1986), which may result from erosion by the Gulf Stream or by the flows themselves, or even from depositional processes, such as the development of "lithoherms," reported by Neumann et al. (1977). 


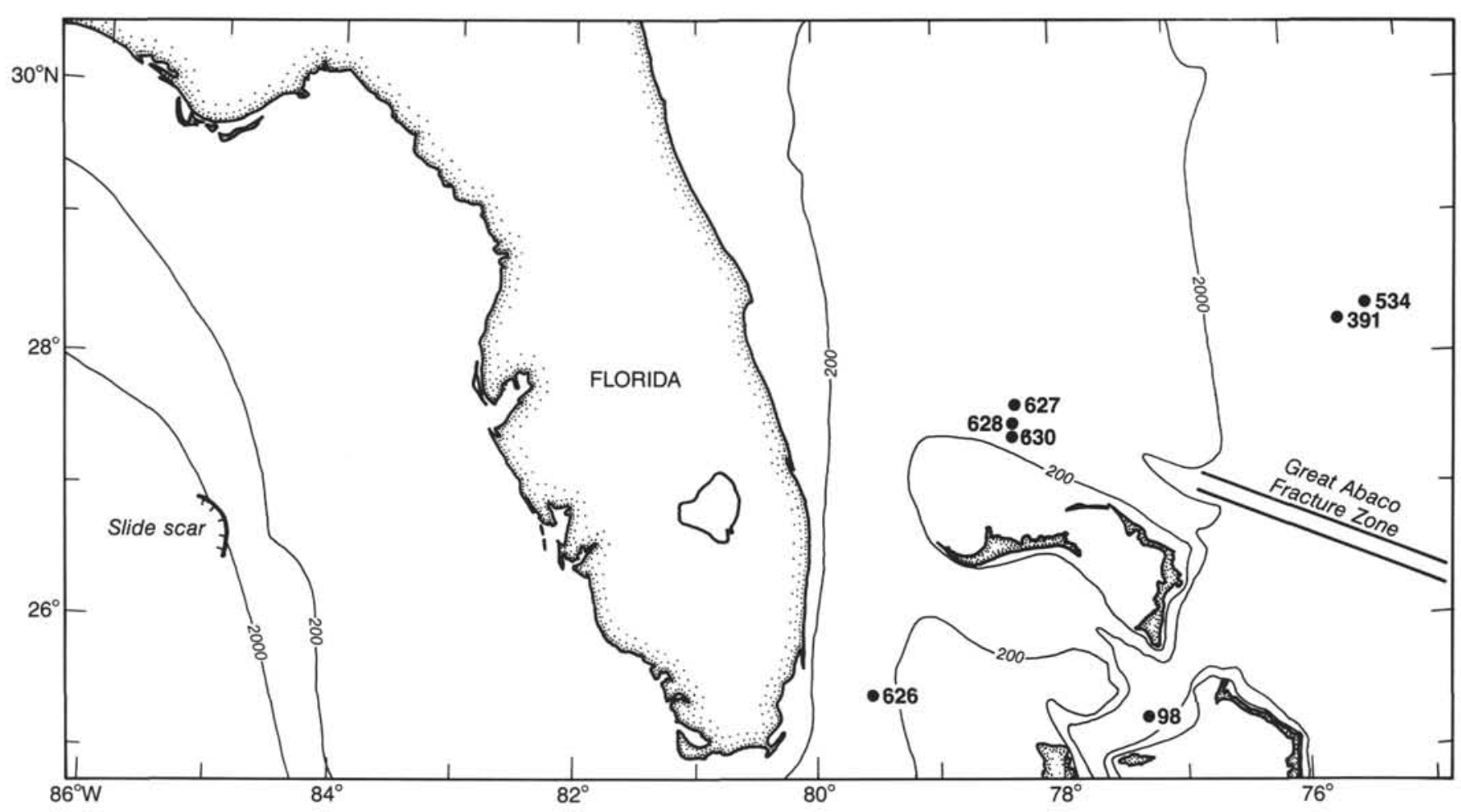

Figure 1. Map showing ODP Sites $626,627,628$, and 630 and DSDP Sites 98,391 , and 534. The slide scar on the west Florida margin, described by Mullins et al. (1986), and the Great Abaco Fracture Zone are also shown. Contours are in meters.

\section{Description of Unit II}

\section{General Characteristics}

Sediments in Unit II (Cores 101-626C-13H through 101-626C$18 \mathrm{H})$ consist predominantly of chalk and limestone clasts in a matrix of calcareous sand and mud. The term "clast" is used here to refer to grain aggregates whose largest dimensions exceed $2 \mathrm{~mm}$. The clast sizes given in the following sections refer to this largest dimension. For this study, Unit II was divided into subunits based on the occurrence of clast-free, ungraded sediment between intervals of clast-bearing, or graded, sediment; Subunit IIC was further subdivided into four divisions (Tables 1 and 2, Fig. 2). Divisions 1 and 2 are differentiated on the basis of clast induration, while divisions 3 and 4 form graded units (Table 2). The contacts between divisions 1, 2, and 3 are gradational, and the contact between divisions 3 and 4 falls between two cores.

Clasts are not uniformly distributed throughout the cores; some grading is evident, and some intervals contain concentrations of clasts (Table 2). Although the maximum clast size may vary (Fig. 2), at any level in the cores a complete range of clast and large skeletal-fragment sizes (up to the maximum) occurs. The level of induration of the clasts varies; chalk and limestone are present, as are friable to unlithified clasts in some intervals. Clasts are predominantly matrix-supported, but some clast support also exists, particularly in Core 101-626C-17H (Fig. 5). The matrix throughout the unit is an unlithified packstone in which the sand-sized grains are composed of planktonic foraminifers and other skeletal fragments, primarily red algae, echinoids, large benthic foraminifers, and bryozoans. The muddy component is predominantly unidentified micrite having subordinate nannofossils. Phosphatic debris is a minor but common component of both clasts and matrix throughout the interval. Table 2 contains information not covered by this general description.

\section{Biostratigraphy}

The planktonic-foraminifer zonation of Bolli and Saunders (1986) was used to assign ages to the sediment. Zones were identified in the matrix sediment based on first appearances of boundary species. Isolated occurrences of younger foraminifers were assumed to represent downhole contamination and were ignored; further details are given by Melillo (this volume). The matrix biostratigraphy of these cores is summarized in Figure 2 and Table 2.

In a few instances, planktonic foraminifers were recovered from or seen in clasts, thus enabling us to assign ages. These ages and those of reworked foraminifers in the matrix are either the same as the depositional age of the surrounding matrix or slightly older, and are early to early middle Miocene (although the shipboard party did observe reworked nannofossils of Oligocene age in the matrix). A clast in Sample 101-626C-16H-7, $57-55 \mathrm{~cm}$, is slightly older than the matrix, although it still correlated with the middle Miocene Globorotalia fohsi fohsi Zone. We assigned a Miocene age to clasts in Samples 101-626C-17H$2,25-27 \mathrm{~cm}$, and 101-626C-16 - $-4,25-27 \mathrm{~cm}$, and a middle Miocene age to a clast in Sample 101-626C-17H-4, 75-76 cm. Another example is discussed in the next section.

A foraminifer zonal boundary occurs in Subunit IIC between divisions 3 and 4. The matrix sediment in Cores 101$626 \mathrm{C}-17 \mathrm{H}$ and $101-626 \mathrm{C}-16 \mathrm{H}$ correlates with the Globorotalia fohsi fohsi Zone (N10 to N11), while that in Core 101-626C$15 \mathrm{H}$ is placed in the Globorotalia fohsi lobata Zone (N11 to N12). A slight uphole increase in clast size (from 10 to $20 \mathrm{~mm}$ ) occurs across the boundary.

\section{Occurrence of Unlithified "Clasts"}

An interval of darker (5Y6/3, pale olive), clast-free sediment occurs in Sample 101-626C-17H-1, 40-45 cm. This interval is 


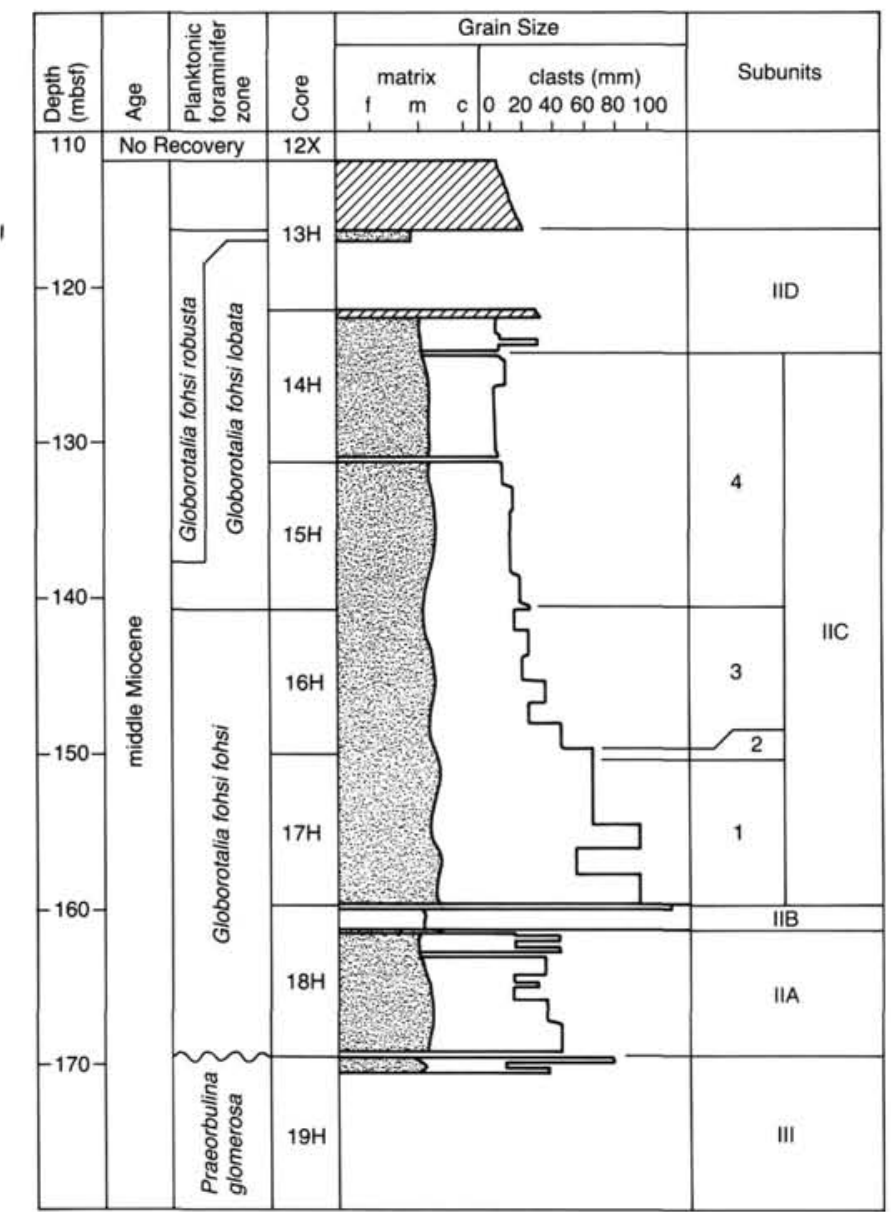

Figure 2. Grain size and biostratigraphy of Cores 101-626C-13H through $101-626 \mathrm{C}-19 \mathrm{H}$. The grain-size chart shows the variation of maximum clast size (clasts defined here as grain aggregates greater than $2 \mathrm{~mm}$ in diameter) and approximate average matrix grain size (shaded area), based on visual estimates. Cross-hatched areas represent downhole contamination. Subunit IIC contains four divisions.

moderately rich in planktonic foraminifers relative to the bulk of the surrounding unlithified sediment, and its top and bottom surfaces are upwardly convex, probably the result of coring disturbance. We did not interpret this as an in-situ bed because a similar unlithified zone occurs in Sample 101-626C-17H-1, 30$35 \mathrm{~cm}$, which does not extend across the entire width of the core. A triangular, unlithified zone of lighter color (10YR $8 / 2$, white) lies immediately above this zone (Fig. 5).

A thin, dark interval with irregular upper and lower surfaces, varying between 1 and $2 \mathrm{~cm}$ thick, occurs in Sample 101$626 \mathrm{C}-16 \mathrm{H}-7,22-24 \mathrm{~cm}$ (Fig. 6). This interval is enriched in nannofossils and planktonic foraminifers and depleted in micrite relative to the over- and underlying material, although a moderate number of neritic benthic foraminifers are present. The interval also has a relatively high content of volcanic glass fragments $(\sim 15 \%)$. Almost all $(>99 \%)$ the planktonic foraminifers exhibit reddish-brown (iron?) staining and are well preserved, although several unstained foraminifers were observed. These are slightly overgrown with calcite. The stained planktonic foraminifers indicate an earliest middle Miocene age (Praeorbulina glomerosa Zone). This is older than the sediments above and below this interval, which correlate with the middle Miocene Globorotalia fohsi fohsi Zone, but is the same age as the sediment at the top of Unit III, although the latter is unstained. The unstained foraminifers in this dark interval indicate a younger age; however, none are restricted to the Globorotalia fohsi fohsi Zone.

The soft clasts in Subunit IIC (described above) are concentrated in division 2 of Subunit IIC, which contains a reduced concentration of lithified clasts. However, some friable clasts also occur below this interval in division 1 .

\section{Clast Petrography}

The clasts in Unit II are predominantly packstones and grainstones of differing skeletal compositions and range from those made up of predominantly skeletal fragments of shallow-water origin to those dominated by pelagic fossils. However, almost all of the clasts examined in thin sections include at least a trace of neritic material, most commonly, red algae or amphisteginid benthic foraminifers. The varying skeletal compositions reflect a range of original depositional environments before incorporation in the sediment gravity flows.

Plate 1, Figure 1, is a clast having skeletal fragments of mostly shallow-water origin. This clast is a poorly sorted packstone to grainstone that contains, in addition to those components shown in the photomicrograph, mollusk shell fragments, bryozoans, and miliolid foraminifers. The latter generally indicate a lagoonal environment. The presence of planktonic foraminifers, however, indicates that the clast sediment did not originate on the bank top, where the proportion of planktonic foraminifers is usually negligible, but that this sediment was probably deposited on the slope, seaward of the platform edge. The clast is well lithified, and the cement is micritic. Most echinoderm fragments have syntaxial rims, and dogtooth spar overgrowths occur on the benthic foraminifers.

The clasts in Plate 1, Figures 2 and 3, contain reduced amounts of shallow-water skeletal fragments and more abundant planktonic foraminifers, indicating origins that are deeper on the slope and farther removed from the bank source. However, Figure 2 is a poorly sorted assemblage having a mud matrix, while Figure 3 shows a well-sorted, laminated deposit that is relatively free of mud and has a high porosity. The clast shown in Plate 1, Figure 2, was subjected to less winnowing, which reflects deposition in a location where current strength was lower.

Sedimentary structures occur rarely in these clasts and are restricted to laminations. Plate 1, Figure 3, shows a thin section of a laminated clast that exhibits grain-size variation and orientation of elongated, skeletal fragments parallel to the laminations. The grain-size variation may have been caused by variations in the bottom-current intensity or by deposition from a turbidity current at the site of the original deposition of the clast sediment.

Plate 1, Figure 4, shows a clast of planktonic foraminifer wackestone to packstone. This clast is moderately well lithified and has a micritic matrix and spar overgrowths on some foraminifers. Although they are not shown in the figure, the clast also contains echinoderm fragments and a trace of red algal fragments. This clast originated in a region of greatly reduced input of sand-sized, shallow-water debris, perhaps toward the lower slope, or on a bypassed region of the slope. Its muddy matrix indicates that the site of original deposition was not subject to strong winnowing by currents.

Coral fragments are rare in the clasts and also in recent sediments (Mullins et al., 1980a). Surprisingly, little evidence of $\mathrm{Ha}$ limeda was observed in these clasts, although this species is a common component of the periplatform sediments of today (Mullins and Neumann, 1979).

\section{INTERPRETATION OF SITE 626 FLOW DEPOSITS}

Many features that help one to identify large sediment gravity flows in outcrops, such as deformation features, sedimentary structures, and textural variations, are not easily recognized in a 


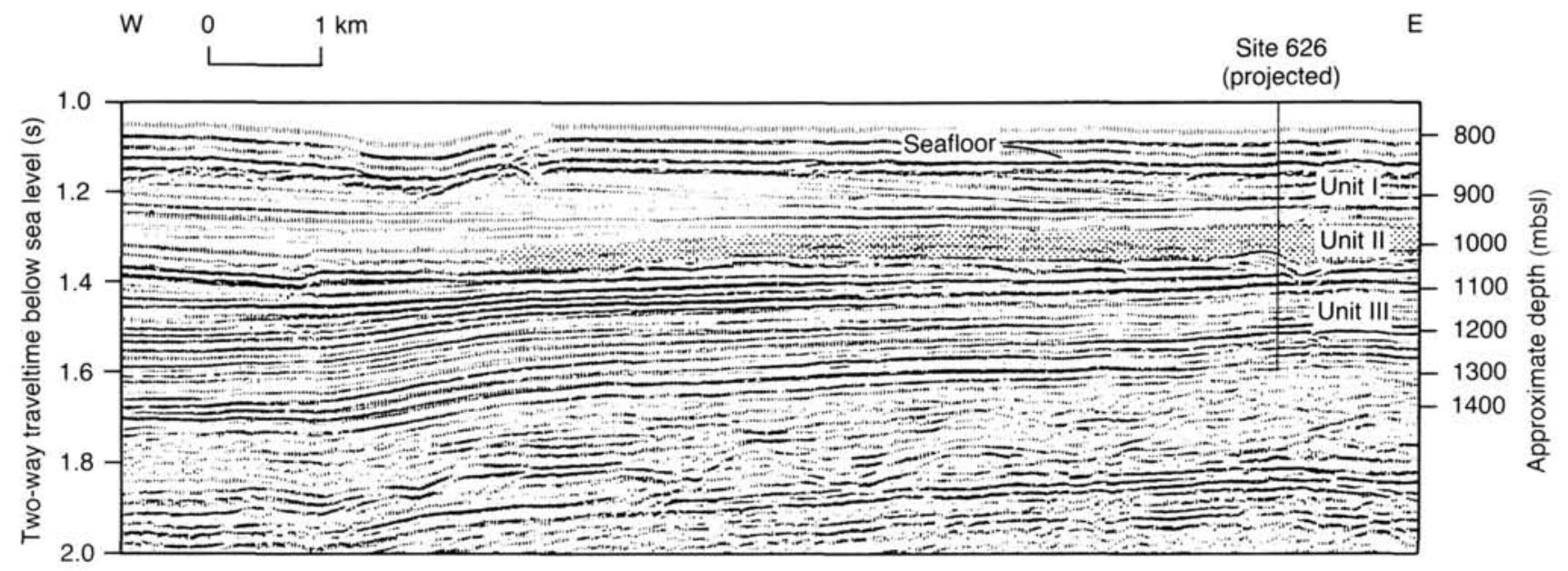

Figure 3. Portion of site-survey profile FS-19. Unit II is shaded. Site 626 is located approximately $2 \mathrm{~km}$ from the profile.

core, and grading is not always present. The presence of clasts in a matrix may result from glacial activity or diagenetic alteration and is not usually enough to justify classifying a deposit as a sediment gravity flow. However, at Site 626 , we know that the depositional environment of the sediment was similar to today's environment, although the bank margin was slightly farther east (Austin, Schlager, et al., 1986; Eberli and Ginsburg, 1987). Furthermore, we do not consider the clasts in Unit II to be insitu diagenetic nodules, such as those described by Mullins et al. (1980b), for the following reasons: (1) some clasts are older than the surrounding matrix; (2) sedimentary structures (parallel laminations), present in some clasts, do not continue into the matrix (Fig. 7); and (3) some angular clasts exhibit planar fracture surfaces (Figs. 5 and 7). With these added constraints, clast-bearing sediment and graded beds are interpreted as sediment gravity-flow deposits, in agreement with Austin, Schlager, et al. (1986). Some lithified fragments occupy the entire width of the core. We interpreted these as clasts, not beds, based on their irregular shapes and their association with other smaller, floating fragments, including single, large skeletal fragments that are not simply fragmented layers.

\section{Origin of Clasts and Matrix}

Clasts that contain purely pelagic or purely shallow-water fossils are rare, and the matrix contains a mixture of pelagic and shallow-water components. Clasts and matrix are similar in composition to the winnowed sand facies (which also has a turbidite component) and to the periplatform sand facies of today's upper slope of the eastern margin of the Straits of Florida (Fig. 8) (Mullins and Neumann, 1979). Mullins et al. (1980a) reported that this sediment contains mixed pelagic and shallow-water components to a depth of at least $600 \mathrm{~m}$. Variations in mud content probably reflect changing current strength, which varies

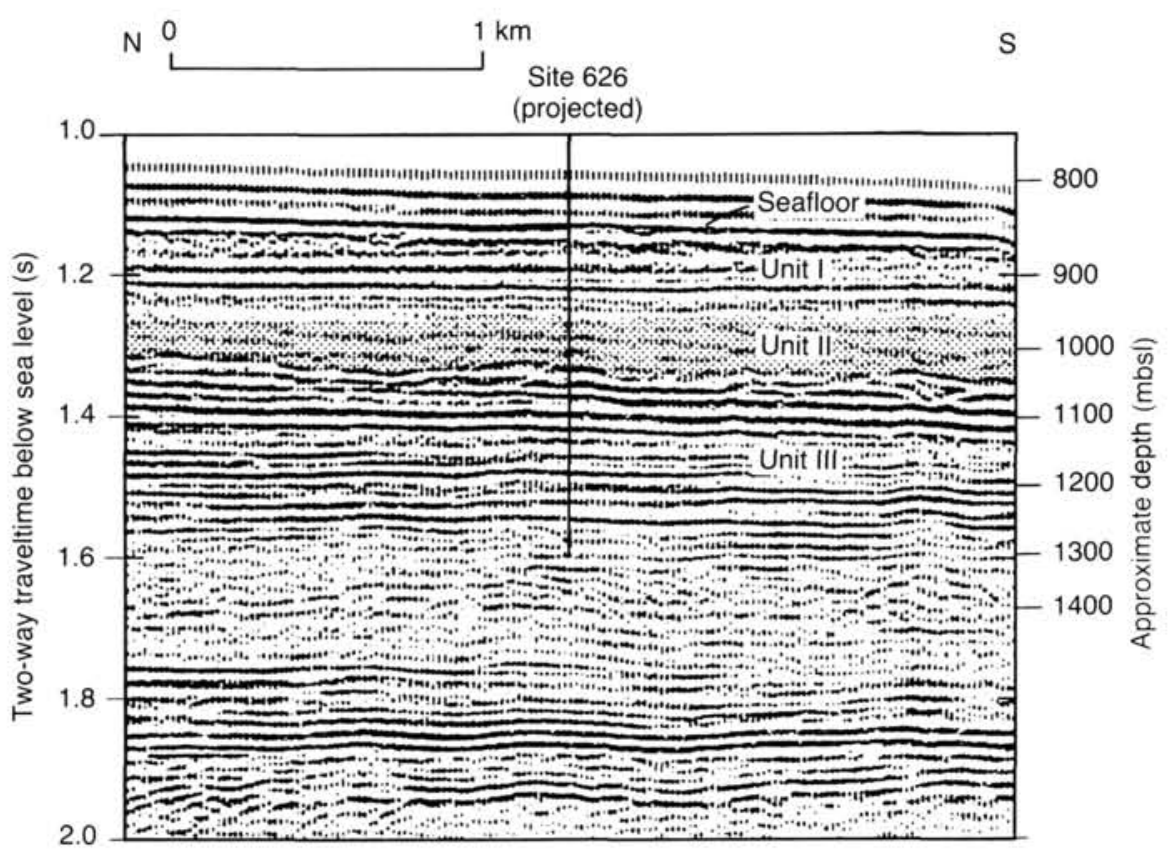

Figure 4. Portion of site-survey profile FS-08. Unit II is shaded. Site 626 is located approximately $0.5 \mathrm{~km}$ from the profile. 
Table 1. Subunit and division boundaries in lithologic Unit II, Site 626.

\begin{tabular}{|c|c|c|c|c|}
\hline Subunit & $\begin{array}{l}\text { Core } \\
\text { interval } \\
(\mathrm{cm})\end{array}$ & Division & $\begin{array}{l}\text { Core } \\
\text { interval } \\
(\mathrm{cm})\end{array}$ & $\begin{array}{c}\text { Thicknes } \\
(\mathrm{m})\end{array}$ \\
\hline IID & $\begin{array}{c}101-626 \mathrm{C}-13 \mathrm{H}-4,20 \\
\text { to } \\
101-626 \mathrm{C}-14 \mathrm{H}-2,124\end{array}$ & & & $>7.6$ \\
\hline \multirow[t]{4}{*}{ IIC } & $\begin{array}{c}101-626 \mathrm{C}-14 \mathrm{H}-2,124 \\
\text { to } \\
101-626 \mathrm{C}-17 \mathrm{H}, \mathrm{CC}\end{array}$ & 4 & $\begin{array}{c}101-626 \mathrm{C}-14 \mathrm{H}-2,124 \\
\text { to } \\
101-626 \mathrm{C}-16 \mathrm{H}-1,0\end{array}$ & 16.4 \\
\hline & & 3 & $\begin{array}{c}101-626 \mathrm{C}-16 \mathrm{H}-1,0 \\
\text { to } \\
101-626 \mathrm{C}-16 \mathrm{H}-7,0\end{array}$ & 9.2 \\
\hline & & 2 & $\begin{array}{c}101-626 \mathrm{C}-16 \mathrm{H}-7,0 \\
\text { to } \\
101-626 \mathrm{C}-17 \mathrm{H}-1,45\end{array}$ & 0.9 \\
\hline & & 1 & $\begin{array}{c}101-626 \mathrm{C}-17 \mathrm{H}-1,45 \\
\text { to } \\
101-626 \mathrm{C}-18 \mathrm{H}-1,0\end{array}$ & 9.1 \\
\hline IIB & $\begin{array}{c}101-626 \mathrm{C}-18 \mathrm{H}-1,0 \\
\text { to } \\
101-626 \mathrm{C}-18 \mathrm{H}-2,7\end{array}$ & & & 1.6 \\
\hline IIA & $\begin{array}{c}101-626 \mathrm{C}-18 \mathrm{H}-2,7 \\
\text { to } \\
101-626 \mathrm{C}-18 \mathrm{H}, \mathrm{CC}\end{array}$ & & & 8 \\
\hline
\end{tabular}

with depth (Mullins et al., 1980b) and time (Mullins et al., 1980a).

Current strength is believed to influence submarine cementation as well as sedimentation in the northern Bahamas (Neumann et al., 1977; Mullins et al., 1980b), and the Gulf Stream probably has flowed through the straits since the Oligocene (Austin, Schlager, et al., 1986). The shallow platform was farther east than today's Great Bahama Bank, but by less than 10 $\mathrm{km}$ at the latitude of Site 626 (Eberli and Ginsburg, 1987). These considerations suggest that recent processes on the margin are similar to those that operated during the middle Miocene (Fig. 8).

The source of the lithified clasts may have been upper-slope hardgrounds and nodules, which have been reported in other parts of the northern Bahamas. North of Little Bahama Bank, hardgrounds at depths shallower than $375 \mathrm{~m}$ are replaced by nodules to $500 \mathrm{~m}$ with unlithified oozes at greater depths, with the decrease in cementation reflecting decreasing current velocity (Mullins et al., 1980b). The eastern margin of the Straits of Florida is a leeward margin, and hardground formation probably is restricted to sea-level lowstands, when transportation of sediment from the bank top ceases (Hine and Steinmetz, 1984). As was reported, the clasts appear to be the same age as or slightly older than the matrix sediment, which suggests that the failure surfaces did not cut deeply into the platform slope, probably because of pervasive slope lithification of the type described previously. Deeper on the slope in the Straits of Florida, the sediment contains little shallow-water debris, but submarine lithification is widespread, and "lithoherms" (Fig. 8) and hardgrounds have developed (Neumann et al., 1977). Material of this sort was not noted in the flow deposits, but the relative enrichment of planktonic foraminifers in Subunit IIA (Table 2) suggests that the flow (or flows) responsible for its deposition tapped sources deeper on the slope than those responsible for Subunits IIC and IID.

\section{Flow Mechanisms}

The thick middle Miocene gravity-flow deposits penetrated at Site 626 in the Straits of Florida (Fig. 1) are examples of a type receiving more attention in the literature (Rupke, 1976; Crevello and Schlager, 1980; Johns et al., 1981; Mutti et al., 1984; Bouma, 1986). The Bouma sequence greatly enhanced understanding of thin-bedded flow deposits, but the sedimentology of thick-bedded flow deposits has not reached this same level of development. Studies of the transport mechanisms and depositional characteristics of thick flows have focused on the behavior of siliciclastic sediments (Middleton and Hampton, 1973, 1976; Carter, 1975; Walker, 1975, 1978; Lowe, 1976, 1982; Hein, 1982; Postma, 1986); however, these studies were used to interpret the deposits at Site 626 in the absence of similar work on carbonates. We cannot draw firm conclusions regarding flow mechanisms in these deposits based solely on observations of cores at a single site. Nevertheless, we can make some interpretations, which are discussed in the following sections.

\section{Subunits IIA and IIB}

Subunit IIA contains clasts up to $40 \mathrm{~mm}$ in diameter; these are concentrated in Sections 101-626C-18H-5 through 101-626C18H-7 (Fig. 2, Table 2). Although weakly developed, normal grading is present in Subunit IIA, and deposition by turbidity currents is a possibility. In addition to fluid turbulence, pebblesized clasts require support mechanisms such as hindered settling, buoyant lift, or dispersive pressure (Lowe, 1982). These mechanisms are related to grain concentration, and a high-density turbidity current is required (Lowe, 1982). However, the presence of a nannofossil-rich unlithified clast in Section 101$626 \mathrm{C}-18 \mathrm{H}-5$ and the indistinct grading suggest that turbulence was weak, at least in the lower part of the subunit. Matrix strength may have been the dominant clast support mechanism in this region, indicating debris flow, according to terminology of Lowe (1979), who used this term to describe all flows exhibiting Bingham plastic behavior whether the matrix strength was cohesive (mudflow) or frictional (grain flow). Subunit IIA may be the deposit of a composite flow made up of a basal debris flow and an overlying turbidity current.

Sections $101-626 \mathrm{C}-18 \mathrm{H}-5$ through 101-626C-18H-7 appear continuous, but increased clast concentration at the base of Section $101-626 \mathrm{C}-18 \mathrm{H}-2$ and reduction in clast concentration in the lower one-half of Section 101-626C-18H-4 (Table 2) may be evidence of flow unit boundaries. Alternatively, these trends may represent stratification in a single flow unit, resulting from flow surges or reworking of the top of the basal layer by the upper part of the flow (Lowe, 1982).

The thin, normally graded bed in Sample 101-626C-18H-2, $17-18 \mathrm{~cm}$, at the top of Subunit IIA (Fig. 9) is probably the deposit of a low-density turbidity current. This bed may be unrelated to the underlying sediment, but such flows may remain after deposition of the coarser sediment from a high-density flow (Lowe, 1982).

Austin, Schlager, et al. (1986) interpreted the glauconitic sediment of Subunit IIB as perennial, or background, sediment, based on its high content of pelagic microfossils, low content of neritic material, and the presence of glauconite-usually, if in situ, an indicator of low sedimentation rates. A piece of lithified grainstone in Sample 101-626C-18H-1, 5-12 cm, may be a thin turbidite, as suggested by Austin, Schlager, et al. (1986). We suggest, however, that this may be a clast from Subunit IIC, as it is located near the top of the core, where downhole contamination is likely (G. Harwood, pers. comm., 1987).

\section{Subunits IIC and IID}

Division 1, between the base of Subunit IIC and Sample $101-626 \mathrm{C}-17 \mathrm{H}-1,45 \mathrm{~cm}$, contains the largest clasts, many of which are angular. A few clasts are friable, suggesting low turbulence. Normal grading of clasts is weakly developed, but in the lowest part of the flow (Sample 101-626C-17H-6, $110 \mathrm{~cm}$, to Section 101-626C-17H, CC) the concentration of large clasts was reduced and inverse grading may exist in this interval (Fig. 7). We interpret these features to be the result of deposition 
Table 2. Distinctive characteristics of sediments in lithologic Unit II, Site 626.

\begin{tabular}{|c|c|c|c|c|c|c|c|c|}
\hline \multirow[b]{2}{*}{ Subunit } & \multirow[b]{2}{*}{ Division } & \multirow{2}{*}{$\begin{array}{l}\text { Thickness } \\
\text { (m) }\end{array}$} & \multirow{2}{*}{$\begin{array}{c}\text { Matrix planktonic } \\
\text { foraminifer } \\
\text { zone }^{1}\end{array}$} & \multirow{2}{*}{$\begin{array}{c}\text { Maximum clast or } \\
\text { skeletal fragment } \\
\text { dimension (uphole } \\
\text { reduction given } \\
\text { where applicable) } \\
\text { (mm) }\end{array}$} & \multirow{2}{*}{$\begin{array}{c}\text { Grading/ } \\
\text { variation in } \\
\text { clast distribution }\end{array}$} & \multicolumn{2}{|c|}{ Distinctive aspects of composition } & \multirow{2}{*}{$\begin{array}{l}\text { Subunit boundary } \\
\text { characteristics }\end{array}$} \\
\hline & & & & & & matrix & clasts & \\
\hline IID & & $>7.6$ & $\begin{array}{l}\text { Globorotalia } \\
\text { fohsi lobata } \\
\text { (N11 to N12) }\end{array}$ & 30 & $\begin{array}{l}\text { Obscured by low } \\
\text { recovery. }\end{array}$ & & & $\begin{array}{l}\text { Upper boundary ob- } \\
\text { scured by low recov- } \\
\text { ery and downhole } \\
\text { contamination. }\end{array}$ \\
\hline \multirow[t]{4}{*}{ IIC } & 4 & 16.4 & $\begin{array}{l}\text { Globorotalia } \\
\text { fohsi lobata } \\
\text { (N11 to N12) }\end{array}$ & $20-5$ & $\begin{array}{l}\text { Normal grading of } \\
\text { clasts. Matrix } \\
\text { ungraded } \\
\text { throughout IIC. }\end{array}$ & & & $\begin{array}{l}\text { Upper boundary is a dark } \\
\text { layer (Core 101-626C- } \\
14 \mathrm{H}-2,124-134 \mathrm{~cm}) \text {, } \\
\text { ungraded, clast-free, } \\
\text { enriched in plank- } \\
\text { tonic foraminifers } \\
\text { and nannofossils with } \\
\text { reduced micrite, } \\
\text { though still some } \\
\text { neritic debris. }\end{array}$ \\
\hline & 3 & 9.2 & $\begin{array}{l}\text { Globorotalia } \\
\text { fohsi fohsi } \\
\text { (N10 to N11) }\end{array}$ & $40-10$ & $\begin{array}{l}\text { Normal grading of } \\
\text { clasts. }\end{array}$ & & & \\
\hline & 2 & 0.9 & $\begin{array}{l}\text { Globorotalia } \\
\text { fohsi fohsi } \\
\text { (N10 to N11) }\end{array}$ & 60 & Ungraded & & $\begin{array}{l}\text { Contains unlithified } \\
\text { clasts. }\end{array}$ & \\
\hline & 1 & 9.1 & $\begin{array}{l}\text { Globorotalia } \\
\text { fohsi fohsi } \\
\text { (N10 to N11) }\end{array}$ & $90-60$ & $\begin{array}{l}\text { Weakly developed } \\
\text { normal grading } \\
\text { of clasts. Re- } \\
\text { duced clast } \\
\text { concentration } \\
\text { below Core 101- } \\
626 \mathrm{C}-17 \mathrm{H}-6 \text {, } \\
115 \mathrm{~cm} .\end{array}$ & & $\begin{array}{l}\text { Largest clasts } \\
\text { mainly angular, } \\
\text { many smaller } \\
\text { clasts rounded } \\
\text { to subrounded. } \\
\text { Clasts predomi- } \\
\text { nantly lithified, } \\
\text { occasionally } \\
\text { friable. }\end{array}$ & \\
\hline IIB & & 1.6 & $\begin{array}{l}\text { Globorotalia } \\
\text { fohsi fohsi } \\
\text { (N10 to N11) }\end{array}$ & & Ungraded & $\begin{array}{l}\text { Abundant planktonic } \\
\text { foraminifers, } \\
\text { common nanno- } \\
\text { fossils, reduced } \\
\text { micrite, glauco- } \\
\text { nitic }(1 \%) \text {. }\end{array}$ & Absent & $\begin{array}{l}\text { Upper boundary proba- } \\
\text { bly between cores, } \\
\text { exact nature obscured } \\
\text { by coring distur- } \\
\text { bance. }\end{array}$ \\
\hline IIA & & 8.0 & $\begin{array}{l}\text { Globorotalia } \\
\text { fohsi foshi } \\
\text { (N10 to N11) }\end{array}$ & 40 & $\begin{array}{l}\text { Weak normal grading } \\
\text { of clasts and } \\
\text { matrix. Greater } \\
\text { concentration of } \\
\text { clasts in Sections } \\
101-626 \mathrm{C}-18 \mathrm{H}-5 \\
\text { to } 6 \text { than above. } \\
\text { High concentra- } \\
\text { tion of clasts at } \\
\text { base of Section } \\
101-626 \mathrm{C}-18 \mathrm{H}-2 \text {. } \\
\text { Clast concentra- } \\
\text { tion depleted, } \\
\text { lower half of } \\
\text { Section } 101- \\
626 \mathrm{C}-18 \mathrm{H}-4 .\end{array}$ & $\begin{array}{l}\text { Slightly enriched in } \\
\text { planktonic } \\
\text { foraminifers } \\
\text { relative to IIC, } \\
\text { IID. }\end{array}$ & $\begin{array}{l}\text { Coral fragments } \\
\text { and Halimeda } \\
\text { in some clasts } \\
\text { (rare in Unit } \\
\text { II). Unlithified } \\
\text { mudstone clast } \\
\text { (50\% nanno- } \\
\text { fossils; Sample } \\
101-626 \mathrm{C}-18 \mathrm{H}- \\
5,43-45 \mathrm{~cm} \text { ). }\end{array}$ & $\begin{array}{l}\text { Capped by thin, normally } \\
\text { graded (crs. to med.), } \\
\text { unlithified packstone } \\
\text { (Core } 101-626 \mathrm{C}-18 \mathrm{H} \text { - } \\
2,7-18 \mathrm{~cm} \text { ); sharp } \\
\text { basal contact, grada- } \\
\text { tional upper contact } \\
\text { with IIB. } \\
\text { Lower boundary between } \\
\text { cores. Obscured by } \\
\text { low recovery in Core } \\
\text { 101-626C-19H. }\end{array}$ \\
\hline
\end{tabular}

\footnotetext{
${ }^{1}$ Bolli and Saunders (1986).
}

from a plastic flow in which matrix strength provided clast support, i.e., a debris flow.

Division 2 (Samples 101-626-17H-1, $45 \mathrm{~cm}$, through 101$626 \mathrm{C}-16 \mathrm{H}-7,22 \mathrm{~cm}$ ) contains the unlithified "clasts," the largest clasts in the division; there are fewer lithified clasts. The unlithified clasts appear to have been transported as coherent units because they are distinct from the surrounding sediment in composition, texture, and color. Division 2 may lie within a region of exceptionally low shear stress and perhaps may even form part of a rafted plug (Enos, 1977).

Division 3, between Sections 101-626C-16H-7 and 101-626C$16 \mathrm{H}-1$, exhibits coarse-tail grading and contains clasts of up to $40 \mathrm{~mm}$ in diameter at its base. We interpreted this division to be the deposit of a high-density turbidity current. Clasts are slightly larger at the base of division 4 than at the top of division 3. In addition, a foraminifer zonal boundary falls between these divisions (see above). The presence of coarse-tail grading and the absence of Bouma divisions suggest that the flow responsible for division 4 was also a high-density turbidity current.

In summary, we interpreted Subunit IIC to contain two flow deposits. This interpretation disagrees with that of Austin, Schlager, et al. (1986), who considered this interval to be the deposit of a single flow. Divisions 1, 2, and 3 represent the 19 -m-thick deposit of a single, composite sediment gravity flow, having both plastic and fluidal regions. Large clasts were concentrated in a basal debris flow (divisions 1 and 2), where matrix strength was the dominant support mechanism. Overlying this flow was a high-density turbidity current (division 3). Transitions between these divisions appear gradational, but the possible existence of further flow-unit boundaries, perhaps between cores, cannot be ruled out. Division 4 is probably the deposit of a separate high-density turbidity current, because it is unlikely that a biostratigraphic zonal boundary could be preserved intact in the deposit of a single sediment gravity flow, especially one in which 


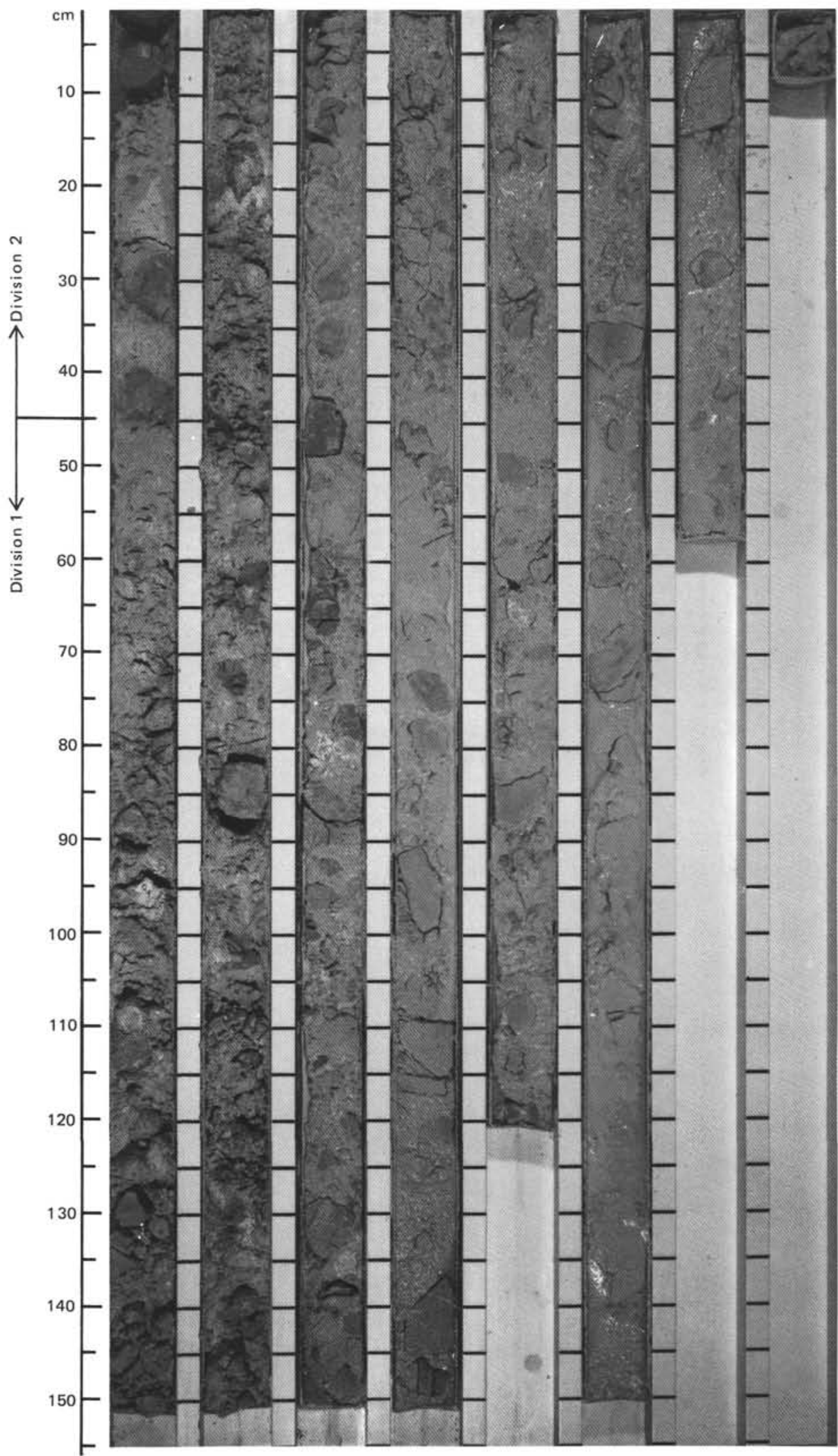

Figure 5. Core 101-626C-17H. Note discolored, unlithified zones and absence of lithified clasts in Sample 101-626C-17H-1, 10-45 cm, and reduction of clast concentration below Sample 101-626C$17 \mathrm{H}-6,115 \mathrm{~cm}$. Sections $101-626 \mathrm{C}-1$ and $101-626 \mathrm{C}-2$ were split by wire, while the remainder of the core was split using a saw, which accounts for the disturbance apparent in the upper two sections. 




Figure 6. Dark, unlithified "clast" at 22-24 cm (Sample 101-626C-16H$7,10-35 \mathrm{~cm})$.

turbulent flow prevailed. Further sedimentological evidence of a flow unit boundary, such as a scour surface or perennial sediment, may have been lost between cores.

We interpreted the dark layer at the upper boundary of Subunit IIC (Fig. 10) to be perennial sediment, based on its composition and its lack of both clasts and grading (Table 1). In Unit II, the lack of sediment that can be unequivocally identified as perennial may result from interflow sediment having been eroded by succeeding flows or by the Gulf Stream. Subunit IID is probably the deposit of a separate flow, but low recovery in this subunit prevented a detailed interpretation.

\section{Support Mechanisms in Carbonate Debris Flows}

Mud and grain flows form the end-members of the debrisflow system, but intermediate types in which matrix strength is partly frictional and partly cohesive (Lowe, 1979) are possible. In a plastic flow of the frictional type (a grain flow), dispersive pressure, generated by grain collisions, provides most of the support to the clasts (Lowe, 1982). Pure, unmodified grain flows are limited to thicknesses of about $5 \mathrm{~cm}$ and to slopes near the angle of repose (Lowe, 1976). However, the debris-flow deposits of Unit II are as much as $10 \mathrm{~m}$ thick (divisions 1 and 2, Subunit IIC) and were deposited on a gentle slope; this depositional slope is unlikely to have been greater during the middle Miocene because Great Bahama Bank has been prograding westward and would have been farther distant from Site 626 at the time of deposition than at present (Austin, Schlager, et al., 1986; Eberli and Ginsburg, 1987). Grain flows of greater thickness are possible as a result of density-modification (in which the mixture of fine grains and pore fluid increases the buoyant lift on the larger clasts) or of transfer of shear stress from an overlying turbidity current moving in the same direction as, and faster than, the de-

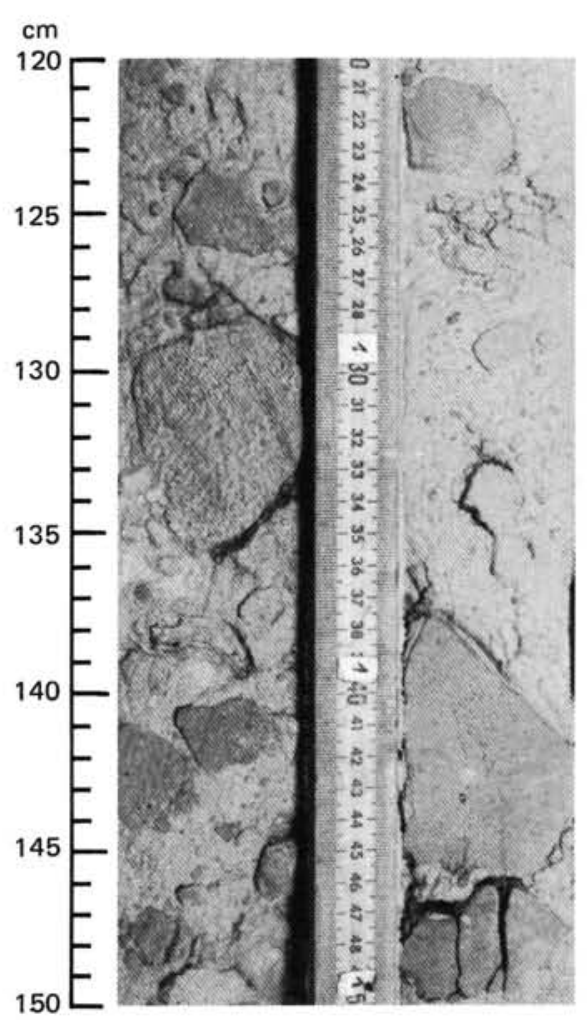

Figure 7. Large clasts in Subunit IIC, Sample 101-626C-17H-3, 120-150 $\mathrm{cm}$ (left) and Sample 101-626C-17H-4, 120-150 cm (right). Note clast with inclined laminations in Sample 101-626C-17H-3, 129-135 cm, and mollusc fragment in Sample 101-626C-17H-3, $138 \mathrm{~cm}$. Both rounded and angular clasts occur.

bris flow (Lowe, 1976). However, if a layer of reduced shear stress existed in the flow, as suggested previously (division 2, Subunit IIC), no large shear stress could have transferred from above the layer to the sediment below.

The presence of friable, unlithified clasts in Unit II indicates that grain interactions were gentle and argues against the support of large clasts by dispersive pressure generated by grain collisions in the inertial regime. The transporting mechanism may have been intermediate between grain- and mudflows, but the presence of clay minerals has been considered necessary to provide cohesive strength in mudflows (Middleton and Hampton, 1973, 1976; Lowe, 1979), and the sediment gravity flows of Site 626 consist of more than $90 \%$ calcium carbonate with no clay (Austin, Schlager, et al., 1986). The influence of fine micritic and nannofossil components on flow rheology has not been documented, but our difficulty in accounting for the Unit II deposits by purely inertial transporting mechanisms suggests that these carbonate fines may serve to increase flow viscosity to some degree, or even to exhibit slight cohesion.

\section{Composite Carbonate Sediment Gravity Flows in the Geological Record}

Thick, composite flows were described by several authors. Crevello and Schlager (1980) inferred that a debris flow having an overlying turbidity current was the flow type responsible for deposits up to $3 \mathrm{~m}$ thick in Exuma Sound. A composite flow mechanism also was proposed for carbonate turbidites of unusual thickness in the Pyrenees, described by Rupke (1976) and Johns et al. (1981). Rupke (1976) described the deposits as graded calcarenite to marlstone units, up to $41 \mathrm{~m}$ thick with underlying slump sheets. However, Johns et al. (1981) considered 
W
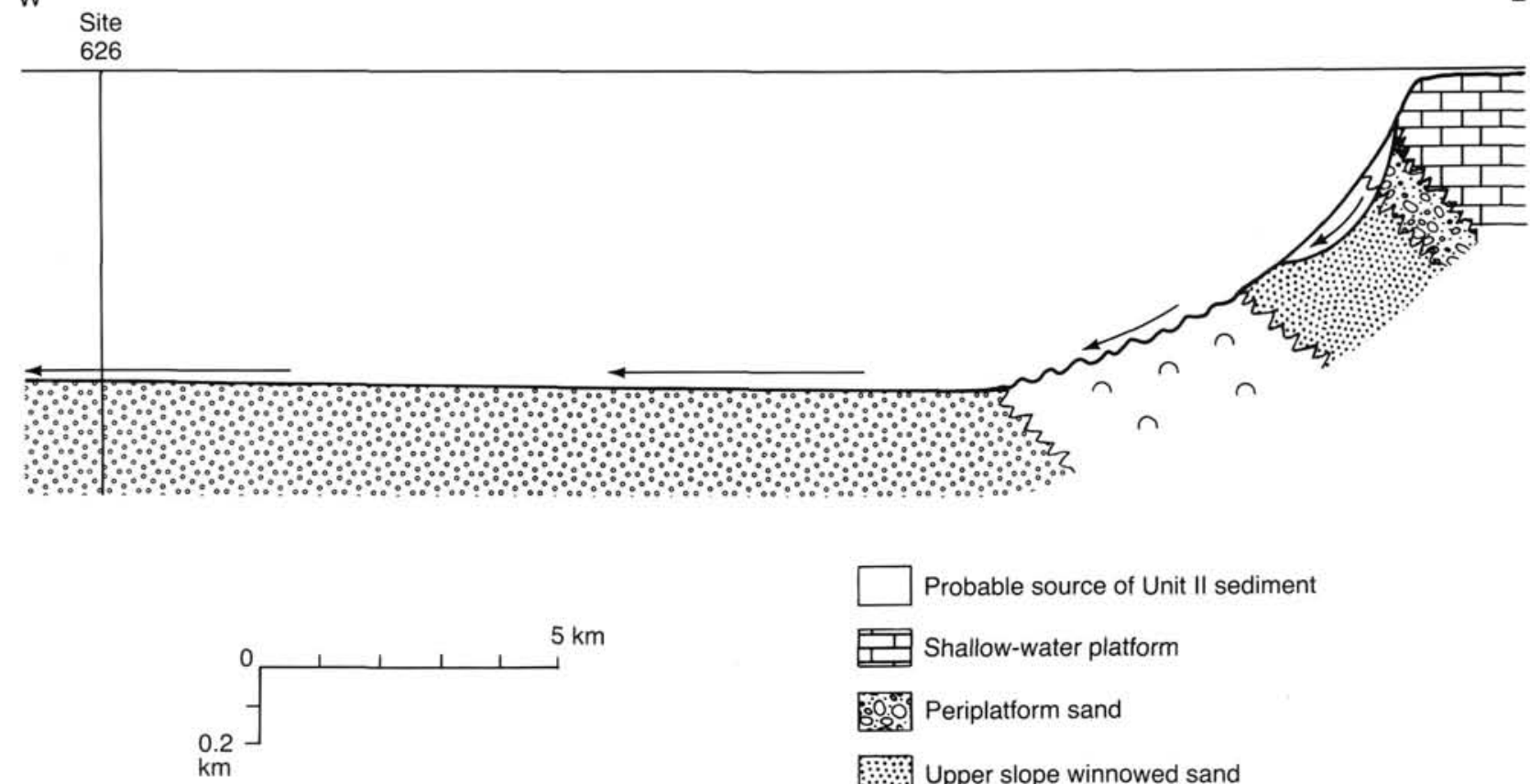

Probable source of Unit II sediment

Shallow-water platform
Leriplatform sand
$\therefore$ Lasinal winnowed sand

Figure 8. Schematic representation of the eastern margin of the Straits of Florida during the middle Miocene showing probable source of Unit II flow deposits. Depositional and diagenetic conditions are assumed to be similar to those of today. Allowance was made for some progradation of the margin since the middle Miocene (facies after Mullins and Neumann, 1979).

that the slump sheets, in at least some instances, were deposited by the same flow responsible for the overlying calcarenite and marlstone. Interpreted in this way, one flow deposit (the Roncal Unit) is almost $100 \mathrm{~m}$ thick and contains slabs of platform carbonate at its base up to $100 \mathrm{~m}$ across and tens of meters thick, with grain size decreasing upward in the deposit. These large slabs were transported "several tens of kilometers" (Johns et al., 1981). The upper divisions of the flow, grading from a lithoclastic breccia to calcareous mudstone, were the deposit of a large turbidity current, while the lower divisions containing giant clasts clearly involved other support mechanisms, such as dispersive pressure (since the matrix lacks mud for cohesive support) and buoyancy (Johns et al., 1981).

Rupke (1976) presented evidence, including vertical and lateral increases in grain size, to show that these thick deposits were the product of the confluence of two or more tributary flows. He also suggested that ponding behind fault-bounded obstructions contributed to their great thicknesses. The possibility that tributary flows were involved in the deposition of the Site 626 flow units cannot be ruled out and should be kept in mind when analyzing any additional data obtained in the region.

\section{REGIONAL SYNTHESIS}

Several sediment gravity-flow depositional events occurred in the region during the middle Miocene (Fig. 1). In this section we discuss these events and their correlation with the deposits of Unit II at Site 626.

\section{Northern Margin of Little Bahama Bank}

Seismic profiles from the site survey for those sites north of Little Bahama Bank revealed the presence of large-scale slumps of middle Miocene age, which occurred as "an exceptional event in the slope's history" (Harwood and Towers, this volume). Drilling at Sites 627 and 628 did not provide such strong evidence of a regional middle Miocene sediment gravity-flow event, but Miocene sediment gravity-flow deposits were cored at these sites (Austin, Schlager, et al., 1986). The following is a brief summary of these results.

An 8-m-thick deposit occurs in Samples 101-627B-19X-1, 12 $\mathrm{cm}$, through 101-627C-19X-6, $50 \mathrm{~cm}$, and consists of clasts floating in a calcareous ooze matrix. The age assigned to the sediment is latest early to earliest middle Miocene (Globigerinatella insueta or Praeorbulina glomerosa zone, N7 to N8), slightly older than Unit II at Site 626. The matrix is unlithified and rich in planktonic foraminifers and nannofossils, which suggests initial deposition beyond the influence of bank-derived material. The clasts consist of unlithified ooze (lighter in color than the matrix), dark mudstone, and some chalks. The sediment has a soupy consistency, and sedimentary structures are not apparent. Some type of flow origin seems likely, and the slightly cohesive nature of the matrix and the softness of the clasts point to a plastic laminar flow, possibly a cohesive mudflow. Other, thinner $(<1.5 \mathrm{~m})$ flow deposits occur above Core 101-627B-19X, including clast-free and clast-bearing deposits. An unconformity, underlain by Eocene sediments (including silicified limestone), occurs beneath the deposit in Core 101-627B-19X.

Middle and upper Miocene (Globorotalia fohsi lobata/robusta to Neogloboquadrina acostaensis zones, N11 to N17) sediment gravity-flow deposits occur at Site 628. These flows appear to be mostly turbidites and often exhibit sharply defined bases and finer grained, more lithified tops. The maximum flow thickness is about $1.5 \mathrm{~m}$, although occasional lithified clasts in Cores 101-628A-14H and 101-628A-15H could be components 


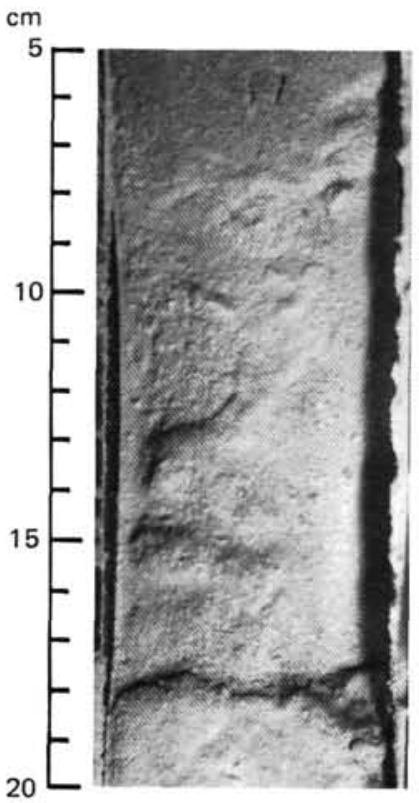

Figure 9. Thin, graded, unlithified packstone capping Subunit IIA. Note sharp basal contact and gradational top. (Sample 101-626C-18H2, 5-20 cm.)

of flows and, if so, the maximum thickness would be about 6 $\mathrm{m}$. These flows consist predominantly of calcareous ooze, rich in planktonic foraminifers and nannofossils, and consequently are very different from the sandy flow deposits of Site 626 . The sediment immediately overlying and underlying this interval is predominantly calcareous ooze without sediment gravity-flow deposits.

\section{Blake-Bahama Basin}

The sediment gravity flows at Site 626 occurred during the deposition period of the Great Abaco Member of the Blake Ridge Formation in the Blake-Bahama Basin. The Great Abaco Member consists of a series of sediment gravity-flow deposits, interspersed with perennial sediment having a total thickness of approximately $500 \mathrm{~m}$ where it was penetrated during DSDP Leg 44 at Site 391 (Benson, Sheridan, et al., 1978). It ranges from early Miocene (Catapsydrax dissimilis to C. stainforthi zones, N5 to N6) to late Miocene (upper Neogloboquadrina acostaensis Zone, N17). The flows responsible were interpreted as being mostly turbidity currents but with some debris flows (mostly lower Miocene; Bliefnick et al., 1983). The thickest flows (up to $66 \mathrm{~m}$ ) and highest sedimentation rates occurred during the middle Miocene Praeorbulina glomerosa to Globorotalia fohsi peripheroronda zones (N8 to N9) (Benson, Sheridan, et al., 1978), between 15.2 and $16.6 \mathrm{Ma}$, using the time scale of Berggren et al. (1985). These flows appear to be only slightly older than the large flows of Site 626 , which probably occurred between 12.6 and 15.2 Ma, based on the same time scale (Globorotalia fohsi fohsi to Globorotalia fohsi lobata zones, N10 to N12). A second peak in sedimentation rate occurred during the middle Miocene Globorotalia fohsi lobata to Globorotalia fohsi robusta zones (N12 and N13) (Benson, Sheridan, et al., 1978), between 11.5 and $13 \mathrm{Ma}$ (Berggren et al., 1985).

Despite Site 391's lying below the CCD during the middle Miocene (Jansa et al., 1979), these flows are composed mostly of calcium carbonate, some of which is of shallow-water origin. Benson, Sheridan, et al. (1978) suggested that the material for the flows had both a shallow source on Little Bahama Bank (near the Great Abaco Canyon) and a deeper source on the Blake Plateau.

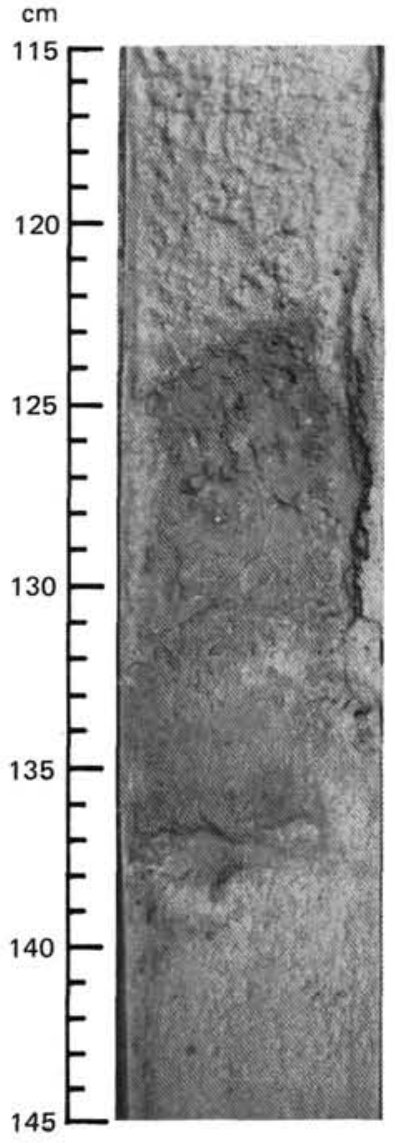

Figure 10. Upper boundary of Subunit IIC. (Sample 101-626C-14H-2, $115-145 \mathrm{~cm}$.)

\section{West Florida Margin}

Mullins et al. (1986) reported a major submarine slide scar off the west coast of Florida, the result of catastrophic collapse of the west Florida carbonate platform. The scar is $120 \mathrm{~km}$ long, and the sediment involved in the slide is 300 to $350 \mathrm{~m}$ thick. Mullins et al. (1986) assigned an early middle Miocene age to this feature, which correlates well with the Straits of Florida and Little Bahama Bank deposits and the periods of peak sedimentation rate in the Blake-Bahama Basin. The proximity in time and space of these events suggests a common cause.

\section{TRIGGER MECHANISMS}

The tendency of carbonate platforms to build up to sea level, given favorable environmental conditions, has been well documented (Schlager, 1981). A highstand that floods the platform, therefore, provides the optimum shallow-water conditions for carbonate production on the bank top. In the hypothesis of highstand shedding, overloading of the slopes with sediment produced under such conditions should result in an increase in the frequency of sediment gravity flows (Mullins, 1983). Shanmugam and Moiola (1984) suggested a modification of the highstand shedding hypothesis whereby an increase in the frequency of sediment gravity flows should accompany the initial lowering of sea level following a highstand. Currents and waves then exert their greatest influence on the platform sediment before its exposure to meteoric diagenesis. A large volume of sediment may be swept off the platform during this period, potentially resulting in oversteepening of the slope and gravitational instability.

Rupke (1976) and Johns et al. (1981) favored large earthquakes as the trigger mechanism for the exceptionally large 
flows in the Pyrenees, which occurred (like those in the Florida/ Bahamas region) against a background of more gradual sedimentation and which appear to have been the result of rare, catastrophic events. Cook et al. (1972) also preferred an earthquake as the trigger for the flows responsible for Devonian carbonate megabreccias in Alberta. They stressed the ability of earthquakes to fracture lithified material to considerable depths, an attribute which is particularly relevant to the massive west Florida collapse. Mutti et al. (1984) invoked earthquakes as the most likely cause of megaturbidites in the northern Appenines of Italy, based largely on consideration of repeat times, and introduced the term "seismoturbidite" to describe such deposits.

We attempted to correlate the flow events of Site 626 with the sea-level curve of $\mathrm{Haq}$ et al. (1987). The planktonic foraminifer zonation used here is that of Bolli and Saunders (1986), while the zonation used by Haq et al. (1987) was that of Stainforth et al. (1975). These schemes differ in the range of interest in that the Globorotalia fohsi fohsi Zone of Bolli and Saunders (1986) correlates with the upper two-thirds of that of Stainforth et al. (1975). Subunits IIA to IIC, division 2, therefore, correlate with a period of falling sea level, a lowstand, and a period of rising sea level on the short-term eustatic curve of Haq et al. (1987) (Fig. 11). Subunit IIC, division 3, however, lies within the Globorotalia fohsi lobata Zone, which correlates with a highstand on the short-term eustatic curve, and the beginning of the subsequent fall (Fig. 11).

The scarity of forms transitional between Globorotalia fohsi fohsi and Globorotalia fohsi lobata suggests that the sediments of Subunits IIA to IIC (divisions 1 and 2) are not contained in the upper part of the Globorotalia fohsi fohsi Zone, but this is speculative. The timing of the flows with respect to sea-level variations cannot be constrained well enough at this stage to enable us to correlate precisely the flow events of Subunits IIA to IIC with periods of either high sea-level stands or the initial lowering on Haq et al.'s (1987) curve. In addition, higher frequency cycles than those shown by Haq et al. (1987) may have existed (Hine and Steinmetz, 1984), which would further complicate correlation. The data do not, however, preclude such a correlation. Mullins et al. (1986) favored oversteepening of the platform slope as a consequence of high sedimentation rates during a high sea-level stand as the primary cause of the failure of the west Florida margin. However, they acknowledged that other forces may have been involved.

The flows of the Straits of Florida, the collapse of the west Florida margin, and the slumps north of Little Bahama Bank occurred in locations where off-bank transportation of platform sediment during or immediately following a sea-level highstand could affect slope stability. However, flows that occurred during periods of peak sedimentation rate in the Great Abaco Member differ in that most of these sediments originated at depths below the influence of sea-level variation. A major shallow-water component is not noted more recently than foraminifer zones N7 to N8 (Benson, Sheridan, et al., 1978). Benson, Sheridan, et al. (1978) and Bliefnick et al. (1983) favored earthquake activity as the cause of these flows and suggested that movement may have occurred during the Miocene on the Great Abaco Fracture Zone and other faults in the northern Bahamas related to tectonic interaction between the Caribbean and North American plates. However, major convergence between these plates had ended by the middle to late Eocene (Austin, pers. comm.; Ball et al., 1985) so that while earthquakes may have triggered the flows, their origins remain unclear. Eberli and Ginsburg (1987) reported faulting within the Great Bahama Bank, although they suggested that the most recent age of tectonism was late Oligocene.

The characteristics of the Great Abaco Member lead us to support the interpretation of Austin, Schlager, et al. (1986) that tectonic activity triggered a regional, middle Miocene sediment gravity-flow event. Sediment loading of the carbonate platform slopes of Florida and the Bahamas in response to middle Miocene sea-level highstands would have rendered them particularly susceptible to failure.

\section{CONCLUSIONS}

We interpret the sediment of Unit II at Site 626 in the Straits of Florida as the result of deposition by debris flows and highdensity turbidity currents. We suggest that at least one of the flow deposits is a composite flow that comprises a basal debris flow and an overlying high-density turbidity current. At least four major flow units occur, having a maximum thickness of 19 m (Subunit IIA; Subunit IIC, divisions 1 to 3; Subunit IIC, division 4; Subunit IID). The composition of the sediment indi-



Figure 11. Ages of major sediment gravity-flow events: Straits of Florida, west Florida margin, and Great Abaco Member (periods of peak sedimentation rate), together with relative onlap and long- and short-term eustatic sea-level curves (after Haq et al., 1987). 
cates that its source was the upper slope of a carbonate platform. Seismic profiles suggest that this source lay east of Site 626. During the middle Miocene, the platform was slightly farther east than today and had a different geometry (Austin, Schlager, et al. 1986; Eberli and Ginsburg, 1987). The similar ages of the clasts and matrix in the flow deposits suggest that the failure surfaces did not cut deeply into the slope.

Overloading of the platform slope with bank-derived sediment during middle Miocene sea-level highstands may have resulted in gravitational instability, and failure may have been associated with a subsequent decrease in sea level, but biostratigraphic resolution is insufficient for conclusive correlation with the eustatic curve of $\mathrm{Haq}$ et al. (1987). Adding to the uncertainty is the possibility of sea-level variations of a higher frequency than those reported by Haq et al. (1987). The sediment gravity-flow deposits of Site 626 occurred as part of a middle Miocene episode of sediment gravity flows involving the west Florida margin, the northern margin of Little Bahama Bank, and the Blake-Bahama Basin. We prefer a tectonic trigger for these regional events, but the platform slopes were probably in a state of incipient failure in response to middle Miocene sea-level highstands.

\section{ACKNOWLEDGMENTS}

This paper developed from a suggestion by W. Schlager. The manuscript benefited from reviews by J. A. Austin, Jr., A. A. Palmer, G. Shanmugam, W. Schlager, S. O. Schlanger, and an anonymous reviewer. We are grateful to R. K. Olsson for helpful discussion and W.P.S. Ventress and Chevron U.S.A. for permission to publish. This work was partially supported by P.R.F. grant No. 0975-300-J266 to S. O. Schlanger.

\section{REFERENCES}

Austin, J. A., Jr., Schlager, W., et al., 1986. Proc. ODP, Init. Repts., 101.

Ball, M. M., Martin, R. G., Bock, W. D., Sylwester, R. E., Bowles, R. M., Taylor, D., Coward, E. L., Dodd, J. E., and Gilbert, L., 1985. Seismic structure and stratigraphy of northern edge of Bahaman-Cuban collision zone. AAPG Bull., 69:1275-1294.

Benson, W. E., Sheridan, R. E., et al., 1978. Init. Repts. DSDP, 44: Washington (U.S. Govt. Printing Office).

Berggren, W. A., Kent, D. V., Flynn, J. J., and Van Couvering, J. A., 1985. Cenozoic geochronology. Geol. Soc. Am. Bull., 96:1407-1418.

Bliefnick, D. M., Robertson, A.H.F., and Sheridan, R. E., 1983. Deposition and provenance of Miocene intraclastic chalks, Blake-Bahama Basin, western North Atlantic. In Sheridan, R. E., Gradstein, F. M., et al., Init. Repts. DSDP, 76: Washington (U.S. Govt. Printing Office), 727-748.

Bolli, H. M, and Saunders, J. B., 1986. Oligocene to Holocene low latitude planktic foraminifera. In Bolli, H. M., Saunders, J. B., and Perch-Nielsen, K. (Eds.), Plankton Stratigraphy: Cambridge (Cambridge University Press), 155-262.

Bouma, A. H., 1986. Megaturbidite, an acceptable term? AAPG Bull., 70:568. (Abstract)

Carter, R. M., 1975. A discussion and classification of subaqueous mass-transport with particular application to grain-flow, slurry-flow, and fluxoturbidites. Earth-Sci. Rev., 11:145-177.

Cook, H. E., McDaniel, P. N., Mountjoy, E. W., and Pray, L. C., 1972. Allochthonous carbonate debris flows at Devonian bank (reef) margins, Alberta, Canada. Bull. Can. Pet. Geol., 20:439-497.

Crevello, P. D., and Schlager, W., 1980. Carbonate debris sheets and turbidites, Exuma Sound, Bahamas. J. Sediment. Petrol., 50:11211148.

Eberli, G. P., and Ginsburg, R. N., 1987. Segmentation and coalescence of Cenozoic carbonate platforms, northwestern Great Bahama Bank. Geology, 15:75-79.

Enos, P., 1977. Flow regimes in debris flow. Sedimentology, 24:133142.

Haq, B. U., Hardenbol, J., and Vail, P. R., 1987. Chronology of fluctuating sea levels since the Triassic. Science, 235:1156-1167.

Hein, F. J., 1982. Depositional mechanisms of deep-sea coarse clastic sediments, Cap Enrage Formation, Quebec. Can. J. Earth Sci., 19: $267-287$.
Hine, A. C., and Steinmetz, J. C., 1984. Cay Sal Bank, Bahamas-a partially drowned carbonate platform. Mar. Geol., 59:135-164.

Jansa, L. F., Enos, P., Tucholke, B. E., Gradstein, F. M., and Sheridan, R. E., 1979. Mesozoic-Cenozoic sedimentary formations of the North American Basin, western North Atlantic. In Talwani, M., Hay, W., and Ryan, W.B.F. (Eds.), Deep Drilling Results in the Atlantic Ocean: Continental Margins and Paleoenvironment, Maurice Ewing Series 3: Washington (Am. Geophys. Union), 1-57.

Johns, D. R., Mutti, E., Rosell, J., Seguret, M., 1981. Origin of a thick, redeposited carbonate bed in Eocene turbidites of the Hecho Group, south-central Pyrenees, Spain. Geology, 9:161-164.

Lowe, D. R., 1976. Grain flow and grain flow deposits. J. Sediment. Petrol., 46:188-199.

1979. Sediment gravity flows: their classification and some problems of application to natural flow deposits. In Doyle, L. J., and Pilkey, O. H. (Eds.), Geology of Continental Slopes. Soc. Econ. Paleontol. Mineral. Spec. Publ., 27:75-82.

1982. Sediment gravity flows: II. depositional models with special reference to the deposits of the high-density turbidity currents. J. Sediment. Petrol., 52:279-297.

Middleton, G. V., and Hampton, M. A., 1973. Sediment gravity flows: mechanics of flow and deposition. In Turbidites and Deep-Water Sedimentation. Soc. Econ. Paleontol. Mineral., Pacific Sect., Short Course Lecture Notes, 1-38. 1976. Subaqueous sediment transport and deposition by sediment gravity flows. In Stanley, D. J., and Swift, D.J.P. (Eds.), Marine Sediment Transport and Environmental Management: New York (Wiley), 197-218.

Mullins, H. T., 1983. Eustatic control of turbidites and winnowed turbidites. Comment. Geology, 11:57-60.

Mullins, H. T., and Neumann, A. C., 1979. Deep carbonate bank margin structure and sedimentation in the northern Bahamas. In Doyle, L. J., and Pilkey, O. H. (Eds.), Geology of Continental Slopes: Soc. Econ. Paleontol. Mineral. Spec. Publ., 27:165-192.

Mullins, H. T., Neumann, A. C., Wilber, R. J., Hine, A. C., and Chinburg, S. J., 1980a. Carbonate sediment drifts in the northern Straits of Florida. AAPG Bull., 64:1701-1717.

Mullins, H. T., Neumann, A. C., Wilber, R. J., and Boardman, M. R., 1980b. Nodular carbonate sediment on Bahamian slopes: possible precursors to nodular limestones. J. Sediment. Petrol., 50:117-131.

Mullins, H. T., Gardulski, A., and Hine, A. C., 1986. Catastrophic collapse of the west Florida carbonate platform margin. Geology, 14: $167-170$.

Mutti, E., Ricci Lucchi, F., Seguret, M., and Zanzucchi, G., 1984. Seismoturbidites: a new group of resedimented deposits. Mar. Geol., 55: 103-116.

Neumann, A. C., Kofoed, J. W., and Keller, G. H., 1977. Lithoherms in the Straits of Florida. Geology, 5:4-10.

Postma, G., 1986. Classification for sediment gravity-flow deposits based on flow conditions during sedimentation. Geology, 14:291294.

Rupke, N. A., 1976. Sedimentology of very thick calcarenite-marlstone beds in a flysch succession, southwestern Pyrenees. Sedimentology, 23:43-65.

Schlager, W., 1981. The paradox of drowned reefs and carbonate platforms. Geol. Soc. Am. Bull., 92:197-211.

Shanmugam, G., and Moiola, R. J., 1984. Eustatic control of calciclastic turbidites. Mar. Geol., 56:273-278.

Sheridan, R. E., Gradstein, F. M., et al., 1983. Init. Repts. DSDP, 76: Washington (U.S. Govt. Printing Office).

Stainforth, R. M., Lamb, J. L., Luterbacher, H., Beard, J. H., and Jeffords, R. M., 1975. Cenozoic Planktonic Foraminiferal Zonation and Characteristics of Index Forms. Univ. Kansas Paleontol. Contr., Art. 62.

Walker, R. G., 1975. Generalized facies models for resedimented conglomerates of turbidite association. Geol. Soc. Am. Bull., 86:737748.

1978. Deep-water sandstone facies and ancient submarine fans: models for exploration for stratigraphic traps. AAPG Bull., 62:932-966.

Date of initial receipt: 31 October 1986

Date of acceptance: 3 June 1987

Ms 101B-141 

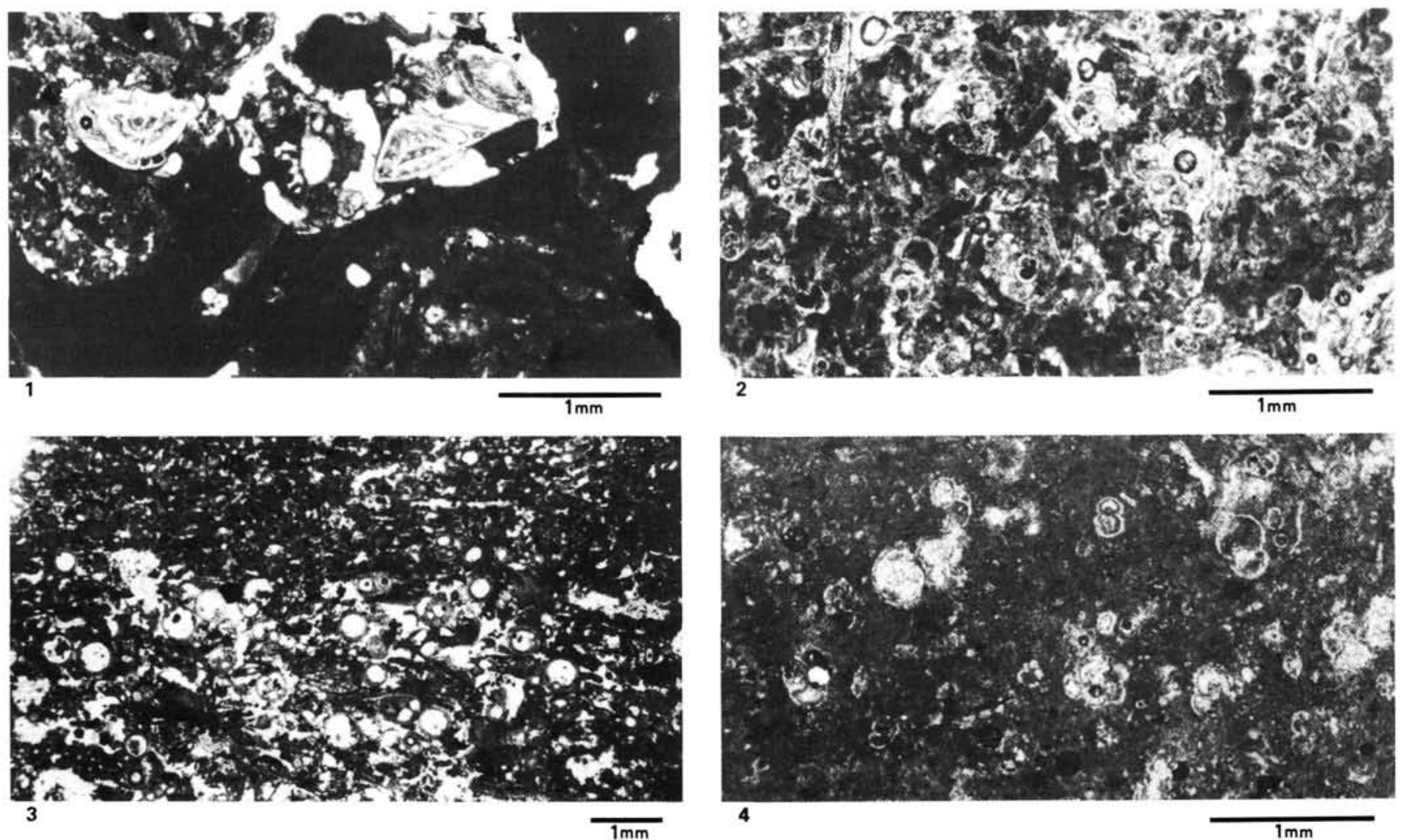

Plate 1. Thin-section photomicrographs of clasts from Unit II. 1. Poorly sorted packstone to grainstone containing encrusting red algae, amphisteginid benthic foraminifers, branching red algae, echinoderm plate fragments, and small planktonic foraminifers. Dogtooth spar overgrowths occur on the benthic foraminifers. The cement is predominantly micritic. (Sample 101-626C-17H-1, 96-98 cm.) 2. Poorly sorted grainstone to packstone. Skeletal fragments include planktonic foraminifers with sparry overgrowths, echinoderm fragments with syntaxial rims, mollusc fragments, and red algae. The cement is micritic. (Sample 101-626C-16H-7, 24-26 cm.) 3. Highly porous grainstone showing contact between two lithotypes, both exhibiting preferential alignment of elongated grains parallel to the boundary. Similar skeletal fragments occur in both the coarse and fine units and include planktonic foraminifers with sparry overgrowths, echinoderm spine and plate fragments, and bryozoans. This sample is from the laminated clast shown in Figure 4. (Sample 101-626C-17H-3, 131-133 cm.) 4. Planktonic foraminifer wackestone to packstone with micritic matrix. Some foraminifers have sparry overgrowths. (Sample 101-626C-16H-5, 68-70 cm.) 